\title{
Which states parties should be held responsible for the implementation of positive obligations under the ECHR in sports-related disputes?
}

\author{
Tsubasa Shinohara ${ }^{1}$ (D)
}

Accepted: 26 October 2021 / Published online: 10 November 2021

(c) The Author(s) 2021

\begin{abstract}
In sports society, awareness of human rights protection has gradually developed and sports governing bodies, such as the International Olympic Committee (IOC) and the Fédération Internationale de la Football Association (FIFA), have striven to commit the implementation of human rights guaranteed by internationally recognised human right treaties in the international community. However, human rights law cannot directly impose any legal obligations on sports governing bodies because they are non-state actors established by domestic private law. In this situation, how can international human rights law apply to the private relationship between non-state actors? According to the European Convention on Human Rights (ECHR), state parties must implement positive obligations to protect individuals against any violations caused by non-state actors within the jurisdiction. To implement the positive obligations under the ECHR, it is necessary to identify which state parties should be held responsible for the implementation in sports-related disputes because, in Mutu and Pechstein v. Switzerland, athletes claimed a violation of the ECHR against Switzerland on the ground that the Court of Arbitration for Sport (CAS) is located in Lausanne, Switzerland. However, it should be considered that Switzerland is not be liable for all violations of the ECHR's rights caused by another state party. In light of this, the purpose of this article is to identify a hypothetical standard for determining which state parties should be held responsible for implementing the positive obligations under the ECHR.
\end{abstract}

Keywords The European Convention on Human Rights (ECHR) · Positive obligations · Private autonomy · Indirect horizontal effect · Human rights · Sports governing bodies · Non-state actors · The United Nations Guiding Principles on Business and Human Rights (UNGPs)

\section{Introduction}

Human rights protection in sports has gradually developed and sports governing bodies, such as the International Olympic Committee $(\mathrm{IOC})^{1}$ and the Fédération Internationale de la Football Association (FIFA), ${ }^{2}$ have striven to commit the implementation of human rights guaranteed by internationally recognised human right treaties in the international community. ${ }^{3}$

However, human rights law cannot directly impose any legal obligations on sports governing bodies because they are non-state actors established by domestic private law. ${ }^{4}$ In this situation, how can international human rights law apply

Tsubasa Shinohara

tsubasa.shinohara@unil.ch

1 University of Lausanne, Lausanne, Switzerland to the private relationship between non-state actors? According to the European Convention on Human Rights (ECHR), ${ }^{5}$ state parties must implement positive obligations to protect

\footnotetext{
1 The IOC has recently started a human rights protection initiative in collaboration with some human rights experts. See IOC (2020).

2 The FIFA established the Human Rights Committee and it published a final report in 2021. See FIFA 2021.

${ }^{3}$ In particular, the FIFA created a human rights clause in Article 3 of the FIFA Statutes. Under this provision, the FIFA has officially engaged in human rights protection in football, but that voluntary duty is not a legal obligation. In 2021, the Court of Arbitration for Sports (CAS) published a document as to human rights in sports arbitration. CAS (2021); See also Schwab (2019).

${ }^{4}$ Łukomski (2013, pp. 67-69).

5 Council of Europe, European Convention for the Protection of Human Rights and Fundamental Freedoms, as amended by Protocols Nos. 11 and 14, 4 November 1950, ETS 5. https://www.echr.coe.int/ Pages/home.aspx?p=basictexts\&c=. Accessed 29 August 2021.
} 
individuals against any violations caused by non-state actors within the jurisdiction. ${ }^{6}$

To implement the positive obligations under the ECHR, it is necessary to identify which state parties to the Council of Europe should be held responsible for the implementation of human rights in sports-related disputes. This is because, in Mutu and Pechstein v. Switzerland, ${ }^{7}$ athletes claimed a violation of their rights guaranteed by the ECHR against Switzerland before the European Court of Human Rights (ECtHR) because the Court of Arbitration for Sport (CAS) is located in Lausanne, Switzerland. ${ }^{8}$ However, it should be considered that Switzerland is not be liable for all violations of the ECHR's rights caused by another state party.

In this connection, in Ali Rlza and Others v. Turkey, ${ }^{9}$ the ECtHR received a complaint against Turkey that the Turkish government infringed the right to a fair hearing under Article 6 of the ECHR even though the case was examined by the CAS and Swiss Federal Tribunal (SFT). ${ }^{10}$ In this case, the Court found a violation of Article 6(1) of the ECHR because of the lack of independence and impartiality of the Arbitration Committee of the Turkish Football Federation (TFF) due to "the vast powers given to the Board of Directors over its organisation and operation". ${ }^{11}$ Therefore, Switzerland is not the only state to ensure the enjoyment of the ECHR's rights in sports-related disputes.

In light of this, the purpose of this article is to identify a hypothetical standard for determining which state parties should be held responsible for implementing the positive obligations under the ECHR. In doing so, this article will be divided into the following sections: After this introduction, it will skim through what is the term 'positive obligations' under the ECHR in relation to non-state actors. Furthermore, it will identify a relationship between sporting regulations and private autonomy under national law. In this regard, it will focus on Swiss law to consider how sports governing bodies create their sporting regulations under Article 60 et seq. of the Swiss Civil Code (SCC). ${ }^{12}$ Then, it will clarify a connection between sports governing bodies and a duty to respect human rights in sports. In doing so, it will refer to the United Nations Guiding Principles on Business and Human

\footnotetext{
$\overline{{ }^{6} \text { Harris et al. }}$ (2018, pp. 24-26).

${ }^{7}$ Mutu and Pechstein v. Switzerland, nos. 40575/10 and 67474/10, Judgment of 2 October 2018, ECtHR.

${ }^{8}$ Mutu and Pechstein v. Switzerland, paras. 62-67.

${ }^{9}$ Ali Riza and Others v. Turkey, nos. 30226/10 and 4 others, Judgment of 28 January 2020, ECtHR; See also Mavromati (2020).

10 Ali Rlza and Others v. Turkey, para. 143.

11 Ali Riza and Others v. Turkey, para. 222.

12 RS 210 (English translation is available at https://www.fedlex. admin.ch/eli/cc/24/233_245_233/en, but it is not an official document). Accessed 29 August 2021.
}

Rights (UNGPs) ${ }^{13}$ Finally, this article will consider a standard for determining which states parties are held responsible for implementing positive obligations under the ECHR in sports-related disputes.

However, the standard is a hypothetical one so that it is necessary to wait for the ECtHR's judgment to know how the Court identifies a connection between human rights obligations and one of the state parties to the Council of Europe in the context of sports.

\section{Positive obligations and 'horizontal effect' under the ECHR: The protection of human rights in the private relationship between non-state actors}

This section, first of all, will skim through the concepts of 'positive obligations' and 'horizontal effect' under the ECHR in order to consider how the ECtHR may apply the Convention to a private relationship between non-state actors within the jurisdiction of the state parties. ${ }^{14}$

\subsection{Positive obligations under the ECHR}

Human rights treaties impose on state parties two types of obligations: negative obligations and positive obligations. The concept of 'negative obligations' means that state parties must refrain from arbitrarily interfering with the rights. ${ }^{15}$ In contrast, the concept of 'positive obligations' signifies that state parties must take necessary measures to protect the ECHR rights from any human rights violations by public and private actors. ${ }^{16}$ Laurens Lavrysen noted that "[i]n terms of the positive/negative obligations dichotomy, the obligations to respect would be considered a negative obligation, whereas the obligations to protect and fulfil would be considered as positive obligations". ${ }^{17}$

\footnotetext{
13 OHCHR, Guiding Principles on Business and Human Rights, HR/ PUB/11/04 (New York and Geneva, 2010), United Nations, available at https://www.ohchr.org/documents/publications/guidingprincipl esbusinesshr_en.pdf. Accessed 29 August 2021.

${ }^{14}$ How the courts recognise positive obligations is not dealt with in this paper, as there is already previous research on the subject. According to Laurens Lavrysen, the Court is based on the following principles: (1) knowledge condition; (2) proximity between the state's conduct and the harm inflicted on the human rights; (3) principle of effectiveness. See Lavrysen (2016, pp. 131-155).

15 Harris et al. (2018, p. 24) and Reid (2015, p. 77).

${ }^{16}$ Hokkanen v. Finland, no. 19823/92, Judgment of 23 September 1994, ECtHR, para. 55; López Ribalda and Others v. Spain [GC], nos. 1874/13 and 8567/13, Judgment of 17 October 2019, ECtHR, paras. 109-111; Reid (2015, pp. 77-78) and Garciandia (2020, p. 180).

17 Lavrysen (2016, Intersentia, p. 12).
} 
However, it is important to note that the ECtHR has not clarified a precise definition of the concept of 'positive obligations' ${ }^{18}$ In Keegan v. Ireland, the Court observed that "the boundaries between the State's positive and negative obligations ... do not lend themselves to precise definition". ${ }^{19}$ In this situation, it would be easy to understand this concept as "obligations to do something" by state authorities to safeguard the ECHR's rights. $^{20}$

In particular, positive obligations may be imposed on state parties even if non-state actors within the jurisdiction violated the rights of individuals. ${ }^{21}$ In this regard, it should refer to Article 1 of the ECHR, which reads as follows:

"The High Contracting Parties shall secure to everyone within their jurisdiction the rights and freedoms defined in Section I of this Convention".

Under this provision, the Court may consider that the scope of positive obligations under the ECHR may extend to the private relationship between non-state actors within the jurisdiction because the state concerned is held responsible for monitoring whether public and private actors within the territory respect the ECHR rights. ${ }^{22}$ In this context, the state parties must take necessary measures to protect individuals against any human rights violations caused by non-state actors.

However, in order to find a violation of positive obligations under the ECHR, the Court must examine, in particular, the following two criteria: (1) knowledge condition and (2) causal link between the state's behaviour and human rights violation.

Regarding the first criterion, the state parties "are aware or should be aware of (the possibility of) a factual disturbance of the 'protected conduct or interests' under the right ('knowledge' condition)" in the context of positive obligations under the ECHR. ${ }^{23}$ The ECtHR also noted in Öneryildiz $v$. Turkey that the state knew or ought to have known that there was a real and immediate risk of human rights

\footnotetext{
18 The ECtHR interpreted this concept in a broad manner so that some argued that using the concept of 'positive obligations' may result in a lack of uniformity and predictability. See Lavrysen (2016, pp. 7-9) and Mowbray (2004, p. 2).

19 Keegan v. Ireland, no. 16969/90, Judgment of 26 May 1994, ECtHR, para. 49.

20 Akandji-Kombe (2007, p. 7).

21 Mégret (2018, pp. 97-99); Clapham, p. 563.

${ }^{22}$ Harris et al. (2018, pp. 799-800); See also ECtHR, Guide on Article 14 of the European Convention on Human Rights and on Article 1 of the Protocol No. 12 to the Convention: Prohibition of discrimination, updated on 31 December 2020, Council of Europe/European Court of Human Rights, 2021, para. 15.

${ }^{23}$ Lavrysen (2014, pp. 169-170).
}

violations caused by public or private activity within the jurisdiction. $^{24}$

In addition to this, the second criterion is the existence of a causal link between the state's behaviour and human rights violations. According to Benedetto Conforti, he explained that "the role of causality has to be stressed in ascertaining the breach of a positive obligation" and thus "[a] conclusion that can be drawn from the Strasbourg case-law is that no violation is found in cases where is lack of a causal link between the behaviour of the state and the event". ${ }^{25}$ To examine whether the causal link exists, the Court must find the foreseeability of the wrongful event that causes a violation of human rights due to the state's omission. ${ }^{26}$ Thus, if the state concerned may predict an occurrence of human rights violations by non-state actors within the territory, and, notwithstanding this, it did not take necessary measures to prevent such violations, it might be considered that the state concerned failed to implement positive obligations under the ECHR.

In light of the foregoing, if the conditions are satisfied, the Court may find a violation of positive obligations under the ECHR. Therefore, the states must take necessary measures to protect individuals against the violations of the ECHR rights caused by non-state actors within the jurisdiction.

\subsection{The 'horizontal effect' of the ECHR on the private relationship between non-state actors}

Although the states must implement positive obligations under the ECHR to protect individuals against any human rights violations caused by non-state actors, should the non-state actors also be held responsible for implementing human rights obligations under the ECHR despite the fact that human rights law cannot impose any legal obligations on the non-state actors?

In this regard, Jean-François Akandji-Kombe explained that:

"The state becomes responsible for violations committed between individuals because there has been a failure in the legal order, amounting sometimes to an absence of legal intervention pure and simple, sometimes to inadequate intervention, and sometimes to a

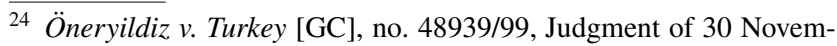
ber 2004, ECtHR, para. 101; This standard is an important element to prove the existence of the state's fault. In this regard, see Stoyanova (2020, pp. 606-612 and pp. 619-620).

25 Conforti (2004, p. 134).

${ }^{26}$ Ibid., p. 135.
} 
lack of measures designed to change a legal situation contrary to the Convention." 27

On this basis, the state parties are held responsible for taking necessary measures to protect individuals in private relationships and prevent human rights violations caused by non-state actors.

Applying the ECHR to the relationship between individuals, private relationships between non-state actors fall within the scope of the ECHR in light of the 'horizontal effect' of the ECHR. ${ }^{28}$ The 'horizontal effect' may be distinguished between 'direct' and 'indirect' horizontal effect. The 'direct' horizontal effect means that human rights law may impose an obligation on non-state actors. ${ }^{29}$ However, this effect cannot be found in the current ECHR system because, as had been explained, it cannot directly impose any obligations on non-state actors. In contrast, 'indirect' horizontal effect of the ECHR signifies that the ECHR may indirectly affect non-state actors that may exercise their power to control over individuals in a specific community, such as family, company and association to implement positive obligations of the state parties to the ECHR. ${ }^{30}$ On this basis, it might be considered that, in sports-related disputes, 'indirect' horizontal effect may play a significant role in applying the ECHR to the private relationship because sports governing bodies may influence their members by means of their sporting regulations and rules. Accordingly, the ECHR would apply to the private relationships between non-state actors in light of the 'indirect' horizontal effect that indirectly requires sports governing bodies to respect due diligence stemming from positive obligations of the state parties to the ECHR. ${ }^{31}$

In this connection, Claire Loven argued that, in order for individuals to bring a case against private actors before the ECtHR, the case must not be 'horizontal' (between private actors), but 'vertical' (between a private actor and the state concerned) relationship to be compatible with the Court's jurisdiction ratione personae. ${ }^{32}$ In doing so, Claire Loven gave an example that:

"This is ... the case when a private actor who had first brought a procedure against another private actor

\footnotetext{
27 Akandji-Kombe (2007, p. 15).

${ }^{28}$ Lavrysen (2016, pp. 78-79) and Akandji-Kombe (2007, p. 14).

29 According to Lottie Lane, direct horizontal effect means that "it would place non-State actors under direct and explicit obligations to respect, protect and/or fulfil human rights". Lane (2018, p. 16).

30 See Lane (2018, pp. 26-29).

${ }^{31}$ Lottie Lane also indicated that "[i]n light of the non-binding nature of the documents analysed and the current international legal framework, we still cannot actually say that non-State actors currently have any binding obligations concerning human rights at the international level". Lane (2018, p. 87).

${ }^{32}$ Loven (2020, pp. 262-263).
}

before the domestic courts, complains about State (in) action in relation to this case before the ECtHR, thus rendering it from a 'horizontal' case (between private actors) into a 'vertical' one (between a private actor and the State)." 33

On this basis, in the context of sports, athletes would claim a violation of their rights in the private relationships before the ECtHR on the ground that the state's in(action) would result in the failure to implement the state's positive obligations under the ECHR.

To sum up, positive obligations required by the ECHR may be imposed on state parties in the case of a violation of human rights caused by non-state actors. In this context, under 'indirect' horizontal effect of the ECHR, such positive obligations may be indirectly imposed on non-state actors within the jurisdiction of the state parties. Thus, when sports governing bodies infringe the ECHR's rights, the state parties must implement the positive obligations required by the ECHR through taking necessary measures to protect athletes against such violations.

\section{The relationship between sporting regulations and private autonomy under national law}

To implement positive obligations under the ECHR, a question that may arise is whether sports governing bodies are responsible for the implementation of the ECHR's rights even though the ECHR cannot impose any legal obligations on non-state actors.

Before taking into consideration this question, it is necessary to skim through a relationship between sporting regulations created by sports governing bodies established under national private law that may enjoy private autonomy under the freedom of association. ${ }^{34}$ This is because private autonomy gives sports governing bodies a huge discretion to decide what kind of regulations and rules they may create to govern their sports activities. ${ }^{35}$ According to this, for

\footnotetext{
33 Loven (2020, p. 247).

${ }^{34}$ For instance, the freedom of association is guaranteed by Article 23 of the Swiss Constitution.

${ }^{35}$ According to Amadou Diakite v. Fédération Internationale de Football Association (FIFA), the CAS Panel held that "according to Swiss law, associations and, in particular, sports associations have a power (i) to adopt the rules of conducts on which may impose their direct and indirect members and (ii) to apply disciplinary sanctions on their members who do not respect the rules, provided that certain general principles of law - such as the right to be heard and the principle of proportionality - are respected." In this sense, within the private autonomy, sports governing bodies may create their regulations and rules to bind their members in the sports community. Arbitrage TAS 2011/A/2433 Amadou Diakite v. Fédération Internationale de
} 
example, the Fundamental Principle 5 of the Olympic Charter (in force as from 17 July 2020) stipulates that:

“... [sports organisations] have the rights and obligations of autonomy, which include freely establishing and controlling the rules of sport, determining the structure and governance of their organisations, enjoying the right of elections free from any outside influence and the responsibility for ensuring that principles of good governance be applied." 36

In other words, sports federations appertaining to the Olympic Movement may enjoy the autonomy of sports to create their sporting regulations and rules applicable to sports activities. Thus, sports governing bodies may create their own regulations and enforce athletes to be bound by these regulations without political and economic pressure from public authority. ${ }^{37}$ In this context, examining the private autonomy under national private law should be considered as an essential point in this issue. ${ }^{38}$ Thus, this article will use an example of Swiss law because the majority of sports governing bodies, such as the IOC and FIFA, are located in Switzerland.

Under the SCC, sports governing bodies established in Switzerland are recognised as an 'association' under Articles 60 to 79 of the SCC. ${ }^{39}$ According to Margareta Baddeley, Swiss law allows private associations to enjoy "a particularly large degree of autonomy in determining their organization and their rules" (extraordinary private autonomy). ${ }^{40}$ In other words, the Swiss authority is reluctant to intervene in private associations' affairs within its jurisdiction and, thus, such associations may decide themselves without the state intervention. ${ }^{41}$ Under this extraordinary private autonomy, sports governing bodies may create their sporting regulations and rules without state interference. ${ }^{42}$

\section{Footnote 35 (continued)}

Football Association (FIFA), sentence du 8 mars 2012, para. 20 (this award was written in French and thus English sentence is free translation by the author).

${ }^{36}$ See also Rule 2.5. of the Olympic Charter.

37 Chappelet (2010, pp. 11-20).

38 Baddeley (2020, pp. 5-6).

39 RS 210; Baddeley (2020, p. 4).

40 Baddeley (2020, p. 15).

${ }^{41}$ In this regard, Jean-Loup Chappelet noted that "the national courts have been reluctant to intervene in "sporting regulation", which they often consider to be part of the autonomous preserve of the national and international federations". Chappelet (2010, p. 23).

${ }^{42}$ In this regard, the SFT also noted in Caster Semenya case that "[i] $t$ is primarily up to the sports federations to determine the extent to which a particular physical advantage is likely to distort competition" (free translation by the author). This phrase may be interpreted that sports governing bodies enjoy a private autonomy to decide themselves to create their sporting regulations and rules. See TF 4A_248/2019 et 4A_398/2019 A c. IAAF et Athletics South Africa,
More importantly, the private autonomy is not unlimited and may be restricted by the concept of 'public policy'. However, what is the concept of 'public policy' under the Swiss legal regime? In this regard, the concept of 'public policy' may be found in Article 190 (2) (e) of the Swiss Private International Law Act (PILA), which reads as follow:

"Proceedings for setting aside the award may only be initiated: ... (e) where the award is incompatible with public policy." ${ }^{33}$

According to the judgment of the SFT, the concept of 'public policy' should be understood that it may apply when there is a violation of fundamental principles of substantive law. ${ }^{44}$ In this sense, the private autonomy under Swiss law may be limited by the concept of 'public policy'.

In short, sports governing bodies may create their sporting regulations and rules under private autonomy under national law if they are not contrary to the public policy of a state where they are located. In this sense, the state authority is reluctant to intervene in their private activities due to the private autonomy. Therefore, the concept of 'private autonomy' has played a role in avoiding being regulated by the state authority.

\section{The responsibility of sports governing bodies to respect athletes' rights under the UNGPs}

Furthermore, are sports governing bodies held responsible for respecting the rights of athletes under the ECHR? In general, they enjoy an extraordinary private autonomy so that they may set up their own rules and regulations without state intervention and, thus, they are reluctant to respect human rights because it would be obstacles to develop economic interests. ${ }^{45}$ In this situation, it is difficult to reflect human rights obligations in their sporting regulations and rules

Footnote 42 (continued)

Athletics South Africa c. IAAF et A., arrêt du 25 août 2020, consid. 9.8.3.3.

${ }^{43}$ RS 291 (English version is available at https://www.fedlex.admin. ch/eli/cc/1988/1776_1776_1776/en). Accessed 29 August 2021.

44 TF 4A_260/2017, X c. Fédération Internationale de Football Association, Arrêt du 20 février 2018, consid. 5.1; Kaufmann-Kohler and Rigozzi (2010, para. 847 g, p. 535).

45 In another field, Suzanne Katzenstein indicated that non-governmental organisations (NGOs) have played an important role in influencing the decision-making and rule-making process of states for human rights protection. However, in the context of sports, non-state actors should also be held responsible for taking necessary measures to protect individuals from human rights violations under the positive obligations of international human rights treaties. See Katzenstein (2017, pp. 336-365). 
due to the private autonomy. In this situation, this section will consider how the UNGPs may play an important role in identifying a responsibility of sports governing bodies to safeguard the rights of athletes in sports.

Before the adoption of the UNGPs, as the first strategic policy initiative to ensure the enjoyment of human rights protection, the United Nations launched the UN Global Compact, which is a non-binding instrument stipulating ten principles for corporate practices. ${ }^{46}$ In particular, Principle 1 of the UN Global Compact provides that:

"Businesses should support and respect the protection of internationally proclaimed human rights." 47

This provision means that "a business should use due diligence to avoid infringing human rights ("do no harm") and should address adverse human rights impacts with which they are involved". 48

In addition to the UN Global Compact, John Ruggie, the Special Representative of the Secretary-General on the issue of human rights and transnational corporations and other business enterprises, described in his reports submitted to the Human Rights Council that:

“... [The framework] comprises three core principles: the State duty to protect against human rights abuses by third parties, including business; the corporate responsibility to respect human rights; and the need for more effective access to remedies. Each principle is an essential component of the framework: the State duty to protect because it lies at the very core of the international human rights regime; the corporate responsibility to respect because it is the basic expectation society has of business; and access to remedy, because even the most concerted efforts cannot prevent all abuse, while access to judicial redress is often problematic, and non-judicial means are limited in number, scope and effectiveness. The three principles form a complementary whole in that each supports the others in achieving sustainable progress." 49

On this basis, John Ruggie proposed a normative framework, so-called the UNGPs, that incorporated the three principles described in the Ruggie reports, for developing human rights protection in the business sector. ${ }^{50}$ This non-legally

\footnotetext{
46 See the UN Global Compact website, https://www.unglobalco mpact.org/what-is-gc/mission/principles. Accessed 29 August 2021.

47 United Nations Global Compact, "The Ten Principles of the UN Global Compact: Principe One: Human Rights”, available at https:// www.unglobalcompact.org/what-is-gc/mission/principles/principle-1. Accessed 29 August 2021.

48 Ibid.

49 Human Rights Council (2008, para. 9).

50 General Principle of the UNGPs.
}

binding instrument was endorsed by the Human Rights Council in June $2011 .{ }^{51}$ The UNGPs has served to elucidate a duty of states to protect human rights and a responsibility of non-state actors to respect them in the private sector.

According to Principle I.1 of the UNGPs, it provides that:

"States must protect against human rights abuse within their territory and/or jurisdiction by third parties, including business enterprises. This requires taking appropriate steps to prevent, investigate, punish and redress such abuse through effective policies, legislation, regulations and adjudication."

This means that the states are held responsible for implementing a duty to protect or positive obligations under international human rights law to "take appropriate steps to prevent, investigate, punish and redress private actor's abuse". ${ }^{52}$

In addition to the state duty under Principle I.1., Principle II. 11 stipulates that:

"Business enterprises should respect human rights. This means that they should avoid infringing on the human rights of others and should address adverse human rights impacts with which they are involved."

Under this provision, it can be understood that non-state actors should also implement a responsibility to respect to refrain from interfering with the rights of individuals guaranteed by international human rights law. ${ }^{53}$ In this sense, it seems that non-state actors may contribute to implementing positive obligations of the states under international human rights law, especially the ECHR, through meeting the responsibility to respect human rights required by the UNGPs.

In short, even though sports governing bodies enjoy an extraordinary private autonomy, they are responsible for implementing a responsibility to respect the rights of individuals required by the UNGPs. In this context, it is important to note that the implementation of the responsibility to respect by sports governing bodies would result in meeting positive obligations (duty to protect) of the states under the ECHR. Therefore, the non-state actors' responsibility to respect required by the UNGPs may be connected with the positive obligations imposed by the ECHR. In consequence, it should be considered that sports governing bodies should meet due diligence to refrain from infringing athletes' rights in their sports activities.

\footnotetext{
51 See https://www.business-humanrights.org/en/big-issues/un-guidi ng-principles-on-business-human-rights/. Accessed 29 August 2021.

52 UNGPs, p. 4.

${ }^{53}$ Furthermore, Principle II. 15 of the UNGPs illustrates how to meet the responsibility to respect human rights.
} 


\section{The standard for determining which states parties are held responsible for implementing positive obligations under the ECHR in sports-related disputes}

Even though private autonomy allows sports governing bodies to create their sporting regulations and rules without any state intervention except for a limitation of public interests, the state parties to the ECHR should implement positive obligations required by the ECHR in light of the concept of 'public policy'. In this situation, how can the Court identify a duty-bearer for a violation of the positive obligations under the ECHR? This is because international sports governing bodies hold a mega sports event around the world so that the venue of sports events are not fixed. Furthermore, the CAS fixed a place of arbitration in Lausanne, Switzerland and, thus, sports-related disputes are governed by Swiss law. ${ }^{54}$

In terms of this situation, should Switzerland be held responsible for all violations of the ECHR's rights even though such violations are caused by another state party? ${ }^{55}$ If so, that consequence might be unreasonable and it appears that the violations of human rights should be imposed on a state that infringed the ECHR rights.

To answer this question, this section will examine the following questions: (1) How does the CAS identify a nexus between sports governing bodies and duty of human rights protection under international human rights law?; and (2) What is the standard for identification of duty-bearer under the ECHR in sports-related disputes?

\subsection{How does the CAS identify a nexus between sports governing bodies and duty of human rights protection under international human rights law?}

On 16 April 2021, the CAS officially published a statement on sports and human rights. ${ }^{56}$ In this statement, it explained how the CAS has dealt with human rights issues in sports to date ${ }^{57}$ and showed how many CAS arbitrators have human rights expertise. ${ }^{58}$ It can be considered that the purpose of this paper is to avoid being criticised due to the lack of human rights involvement by the CAS. In this sense, the CAS strives to commit human rights protection in sports in light of international human rights law.

\footnotetext{
${ }^{54}$ R28 of the CAS Code.

55 Stephanie David also indicated this concern as follows: "can it really fall upon Switzerland to ensure that World Athletics maintains human rights standards across athletics globally?'. See David (2021).

56 CAS (2021).

57 Ibid., pp. 8-16.

58 Ibid., pp. 19-20.
}

Based on this statement, the CAS has already treated how to identify a nexus between sports governing bodies and duty of human rights protection under international human rights law in several CAS awards. This section will elucidate it through the analysis of the CAS awards.

The CAS firstly considered the applicability of one of the international human rights treaties. In Pistorius $v$. IAAF, the IAAF (now, the World Athletics) decided that Oscar Pistorius, double-amputee runner and competed in the 2004 Athens Paralympic Games and participated in the able-bodied category of the IAAF competitions, was ineligible due to his prosthetic device having a competitive advantage over other runners and this violated the IAAF Competition Rule 144.2 (e) ${ }^{59}$ In this case, the CAS Panel held that the IAAF failed to satisfy the burden of proof and, thus, IAAF's decision was revoked with immediate effect and Pistorius was eligible to compete in IAAF-sanctioned events. ${ }^{60}$ In particular, the applicant claimed in this case that the IAAF breached his fundamental right guaranteed by the Convention on the Rights of Persons with Disabilities (CRPD) and its Optional Protocol due to discriminatory ineligibility decision. ${ }^{61}$ In this regard, the CAS observed that:

"Signing a Convention may create an obligation, in the period between signing and ratification, to refrain from acts that would defeat the object and purpose of the treaty. Ratification is an action taken by States that signal an intention to undertake legal rights and obligations contained in the Convention or the Optional Protocol. None of these actions have been taken by the Principality of Monaco, and the UN Convention has not been enacted in its Law." 62

In other words, Monaco had not signed and ratified the CRPD and its Optional Protocol so that it had no legal obligations under these treaties. Accordingly, the place where sports governing bodies are located might be recognised as a standard for determining the place of duty-bearers under international human rights law.

Secondly, the CAS took into account the applicability of the ECHR to sports arbitration seated in Switzerland. In $N A D A \& K N S B$ v. $W$., the CAS Panel observed that "[w] hether or not the ECHR is applicable to arbitration in general or to arbitration agreements specifically, is open to questions" and "[t]he case law of the Swiss Federal Tribunal ...

\footnotetext{
59 Arbitration CAS 2008/A/1480 Pistorius v. IAAF, award of 16 May 2008, p. 5.

${ }^{60}$ Pistorius v. IAAF, Operational paragraphs. 1-2.

${ }^{61}$ Pistorius v. IAAF, paras. 26-30.

62 Pistorius v. IAAF, para. 27.
} 
lacks a clear line". ${ }^{63}$ On this basis, the CAS considered that the ECHR was applicable to arbitration seated in Switzerland. ${ }^{64}$ In other words, the ECHR may apply because Switzerland is one of the state parties to the ECHR. Accordingly, the place of arbitration fixed by arbitration agreements will also be a standard for determining the applicable human rights law to sports-related disputes. ${ }^{65}$

Thirdly, the CAS has considered the applicability of the EU law to non-EU players and clubs. In UMMC Ekateringurg v. FIBA Europe e. V., the appellants, Russian basketball clubs, referred to non-discrimination clause embedded in Article 12 of the EC Treaty on the ground that the FIBA Europe Regulations Governing the Euro League Women basketball tournament (the ELW Regulations) are discriminatory. ${ }^{66}$ The ELW Regulations contained the Elimination Rules prescribing the elimination of clubs in the quarterfinal play offs and in the final $4 .{ }^{67}$ However, the respondent, FIFA Europe, opposed the allegation because Russian legal entities are not entitled to rights under EU law. ${ }^{68}$ The CAS Panel held that:

"The Panel agrees that EC Law is applicable to economic activities carried out in whole or in part within the European Union and is relevant to consider the issues to be determined in this matter. The Panel also notes that there is some case law of the European Court of Justice (...) where it held that the nondiscrimination clause in the Communities - Russia Partnership Agreement meant that a sporting regulation imposing a quota on non-EU players could not be applied to Russian nationals legally employed in the EU. This case is authority that non-discrimination EC Law principles may also apply to Russian Cases involving economic activities in the European Union and in the circumstances, the Panel holds it appropriate within the meaning of R58 of the Code to apply EC

\footnotetext{
63 Arbitration CAS 2010/A/2311 \& 2312 Stichting Anti-Doping Autoriteit Nederland (NADA) \& the Koninklijke Nederlandsche Schaatsenrijders Bond (KNSB) v. W., award of 22 August 2011, para. 15.

${ }^{64}$ NADA \& KNSB v. W., paras. 33-35.

${ }^{65}$ However, the ECHR is not applicable to criminal law proceeding because disciplinary proceeding in sports-related dispute is recognised as private law proceeding. In this regard, the CAS Panel noted that "[a]ccording to Swiss Law sport-related disciplinary proceedings conducted by a sport federation against an athlete are qualified as civil law disputes and not as criminal law proceedings". NADA \& KNSB v. W., para, 33; See also Arbitration 2014/A/3562 Josip Simuni v. Fédération Internationale de Football Association (FIFA), award of 29 July 2014 (operative part of 12 May 2014), para. 40.

${ }^{66}$ Arbitration CAS 2009/A/1788, UMMC Ekateringurg v. FIBA Europe e. V., award of 29 October 2009, paras. 6.

67 UMMC Ekateringurg v. FIBA Europe e. V., p. 2.

${ }^{68}$ UMMC Ekateringurg v. FIBA Europe e. V., para. 7.
}

Law in the present matter, if needed, in particular Art. 81 and 82 EC Treaty." 69

In other words, the EU law that safeguards human rights in the EU cannot apply when applicants are non-EU players and clubs in sports-related disputes. Consequently, the CAS Panel relied on the nationality of players and clubs for determining whether the EU law concerning is applicable to sports-related disputes. ${ }^{70}$

In conclusion, there are largely three standards established by the CAS for determining the place of duty-bearers under international human rights law under the CAS awards: (1) the place where sports governing bodies are located; and (2) the place of arbitration fixed by arbitration agreements; and (3) the nationality of players or clubs. However, the third standard would be taken into account when the applicability of EU law to sports-related disputes is problematic. Thus, the first and second standards might be controversial, but which standards would be suitable for determining which state parties to the ECHR are held responsible for positive obligations under the ECHR in sports-related disputes?

\subsection{The standard for identification of duty bearer under the ECHR in sports-related disputes}

Regarding the implementation of positive obligations, an essential question is whether Switzerland should be held responsible for all violations of human rights under the ECHR in sports-related disputes? In other words, which states parties to the ECHR should be attributed to the positive obligations under the ECHR in sports society? This is because sports-related disputes are of transnational nature and it is difficult to identify who should respect, protect and fulfil human rights obligations guaranteed by the ECHR.

To answer this question, this section will consider a standard for determining who is responsible for the implementation of positive obligations under the ECHR in sportsrelated disputes. ${ }^{71}$ In doing so, as had been mentioned above, it is necessary to identify a causal link between state omission and human rights violations. However, in sports-related disputes, sports competitions are held worldwide, and thus the place of violation might not be in the place of one of the state parties to the ECHR. For instance, the Tokyo Olympic

\footnotetext{
${ }^{69}$ UMMC Ekateringurg v. FIBA Europe e. V., para. 8.

${ }^{70}$ Concerning the applicability of the principle of free movement in the EU, see Arbitration CAS 2012/A/2852, S.C.S. Fotbal Club CFR 1097 Cluj S.A. \& Manuel Ferreira de Sousa Ricardo \& Mario Jorge Quintas Felgueiras v. FRF, award of 28 June 2013, paras. 72-78.

71 According to Vladislava Stoyanova, causation between harm and state omission is important because "[c]ausation implies some nexus/ proximity between the harm sustained by the applicant ... and the alleged omission by the state to ensure the right". See Stoyanova (2018, p. 311).
} 
2020 (or 2021) was held in Tokyo, Japan, which is not a member state to the Council of Europe, but the IOC is located in Lausanne, Switzerland, which ratified the ECHR. If athletes who participated in the Tokyo Olympic Games claimed a violation of the ECHR's rights, who can they sue against? Who will be liable for that violation? How should the ECtHR decide a case where the applicant was not present in one of the state parties to the ECHR?

To consider these questions, according to Article 1 of the ECHR, it may apply when individuals are in the territory of one of the member states to the Council of Europe. Therefore, if the ECtHR finds a place having a causal link between a state omission or non-state actors' omission and human rights violations, it may apply to sports-related disputes.

In light of this situation, this section will consider the following hypothetical standards:

1) The place where the violation of human rights has occurred (the place of violation);

2) The place of arbitration or any other dispute resolution bodies (the place of dispute resolution body);

3) The place where sporting regulations and rules in question were created by sports governing bodies (the place of sports governing bodies)

The reason why this section will take account of these hypothesis criteria is to avoid a situation where Switzerland is held responsible for all violations of human rights under the ECHR even though it has no causal link between a state omission and human rights violations. Furthermore, if the ECtHR may determine the place of duty bearers, it would easily find which states should be responsible for the implementation of positive obligations to take necessary measures to safeguard the ECHR rights in sports-related disputes.

For the first assumption, the Convention, in principle, imposes on the state parties the obligations to respect, protect and fulfil to safeguard individuals under the jurisdiction of one of the state parties against any human rights violations. Furthermore, the ECtHR may also find the extraterritorial application of the ECHR if the external territory is effectively controlled by the state concerned. ${ }^{72}$ In this sense,

\footnotetext{
${ }^{72}$ In Chiragov and Others v. Armenia, the Court stated that " $[\mathrm{t}] \mathrm{he}$ Court has recognised the exercise of extraterritorial jurisdiction by a Contracting State when this State, through the effective control of the relevant territory and its inhabitants abroad as a consequence of military occupation or through the consent, invitation or acquiescence of the government of that territory, exercises all or some of the public powers normally to be exercised by that government." Chiragov and Others v. Armenia [GC], no. 13216/05, Judgment of 16 June 2015, ECtHR, para. 168; See also ICJ, Case Concerning Military and Paramilitary Activities in and Against Nicaragua (Merits), judgment of 27 June 1986, para. 115; In contrast to the 'effective control' test, the International Criminal Court for the former Yugoslavia (ICTY) elaborated the 'overall control' test. See ICTY, Appeals Chamber, Tadić,
}

the violation of the ECHR's rights must be imposed on the state parties where that violation has occurred (the place of violation). If so, when the mega sports events are held in the non-member states to the Council of Europe, the ECHR does not apply and, thus, athletes cannot invoke the ECHR's rights. Based on this standard, some states may avoid being held responsible for violation of the ECHR's rights and thus it would lead to a chaotic situation in which all countries would avoid responsibility for the implementation of human rights.

Secondly, should the Court reply on a standard of the place of arbitration or any other dispute resolution bodies (the place of dispute resolution body)? If so, the CAS Code stipulates that the place of arbitration is Switzerland so that Switzerland must be held responsible for all human rights violations in sports-related disputes. From my perspective, that consequence might not unfair because it should not owe any liability for human rights violations caused by other states.

Finally, should the Court refer to a standard of the place where sporting regulations and rules in question were created by sports governing body? This standard means that the Court considers the place of headquarter of the sports governing body that created sports regulations and rules. As had been cited above, in Pistorius v. IAAF, the IAAF decided that Oscar Pistorius, double-amputee runner and competed in the 2004 Athens Paralympic Games and participated in the able-bodied category of the IAAF competitions, was ineligible due to his prosthetic device having a competitive advantage over other runners and this violated the IAAF Competition Rule 144.2 (e). In this case, the CAS accepted that the CRPD and its Optional Protocol imposed on state parties to refrain from acts or omissions that are contrary to the object and purpose of the CRPD, but the IAAF was located in Monaco which did not ratify the CRPD at the time of this case. Thus, the IAAF did not be bound by the CRPD in this case. ${ }^{73}$ On that basis, the World Athletics has its headquarter in Monaco and thus the Monaco law governs sporting regulations and rules created by the World Athletics. Therefore, it might be considered that there is a clear and close connection between human rights obligations and the place of sporting regulations because the national law allows sports governing bodies to create their sporting regulations and rules that infringes the provisions of the ECHR.

In conclusion, it should be considered that the ECtHR might rely on a standard of the place of sports governing bodies for determining which state parties to the ECHR

\footnotetext{
Footnote 72 (continued)

15 July 1999 (Case no. IT-94-1-A), paras. 116-123; Cassese (2007, pp. 649-668).

${ }^{73}$ Hums et al. (2009, pp. 38-39).
} 
should be held responsible for implementing positive obligations under the ECHR in sports-related disputes. In other words, if sports governing bodies that organise a mega sports event infringe the ECHR rights, the state parties that have the place of sports governing bodies would implement the positive obligations to protect athletes from any human rights violations caused by non-state actors. In this context, when the World Athletics in Monaco violates one of the provisions of the ECHR, Monaco would be a responsible state to implement positive obligations under the ECHR. Therefore, it must take necessary measures to enforce the World Athletics to modify or repeal their sports regulations and rules, despite the fact that the World Athletics enjoys private autonomy under national law. Accordingly, the positive obligations under the ECHR might not attribute to Switzerland if the violation of the ECHR rights occurred outside the jurisdiction of the state parties to the ECHR.

\section{Conclusion}

In conclusion, it can be considered that the ECtHR should use the place of sports governing bodies to determine which state parties should be held responsible for implementing positive obligations under the ECHR. This is because each national law allows sports governing bodies to create their sporting regulations and rules and, thus, the states must monitor whether non-state actors in the jurisdiction respect the ECHR rights or not. Through this, in sports-related disputes, Switzerland will not be the only state that is held responsible for the implementation of the positive obligations under the ECHR.

However, as had been mentioned above, this article is based on a hypothetical approach in order to consider the question of which state parties should be responsible for implementing the positive obligations under the ECHR. Thus, it is necessary to wait for a new judgment rendered by the ECtHR to know how the Court may decide who must implement the obligations under the ECHR.

Funding Open access funding provided by University of Lausanne.

Open Access This article is licensed under a Creative Commons Attribution 4.0 International License, which permits use, sharing, adaptation, distribution and reproduction in any medium or format, as long as you give appropriate credit to the original author(s) and the source, provide a link to the Creative Commons licence, and indicate if changes were made. The images or other third party material in this article are included in the article's Creative Commons licence, unless indicated otherwise in a credit line to the material. If material is not included in the article's Creative Commons licence and your intended use is not permitted by statutory regulation or exceeds the permitted use, you will need to obtain permission directly from the copyright holder. To view a copy of this licence, visit http://creativecommons.org/licenses/by/4.0/.

\section{References}

Akandji-Kombe J (2007) Positive obligations under the European Convention on Human Rights: a guide to the implementation of the European Convention on Human Rights. Human rights handbooks, No. 7, Council of Europe, 2007. https://rm.coe.int/16800 $7 f f 4 d$. Accessed 29 Aug 2021

Baddeley M (2020) The extraordinary autonomy of sports bodies under Swiss law: lessons to be drawn. Int Sports Law J 20(1-2):3-17. https://doi.org/10.1007/s40318-019-00163-6

CAS (2021) Sport and human rights: overview from a CAS perspective (status 16 April 2021). https://www.tas-cas.org/fileadmin/user upload/Human_Rights_in_sport_CAS_report_updated_16.04. 2021_.pdf. Accessed 29 Aug 2021

Cassese A (2007) The Nicaragua and Tadić tests revisited in light of the ICJ judgment on genocide in Bosnia. Eur J Int Law 18(4):649-668. https://doi.org/10.1093/ejil/chm034

Clapham A (2018) Non-state actors. In: Moeckli D et al (eds) International human rights law, 3rd edn. Oxford University Press, Oxford, pp 557-579

Chappelet, J. L. (2010), Autonomy of sport in Europe. Council of Europe Publishing. https://rm.coe.int/autonomy-of-sport-ineurope/168073499f. Accessed 29 Aug 2021

Conforti B (2004) Exploring the Strasbourg Case-Law: reflections on state responsibility for the breach of positive obligations. In: Fitzmaurice M, Sarooshi D (eds) Issues of state responsibility before international judicial institutions: the Clifford chance lectures. Hart Publishing, London, pp 129-138. https://doi.org/ 10.5040/9781472563033.ch-008

David S (2021) The final yards of Caster Semenya's human rights appeal: background \& broader implications. LawInSport, published 13 April 2021. https://www.lawinsport.com/topics/item/ the-final-yards-of-caster-semenya-s-human-rights-appeal-backg round-broader-implications?utm_content $=162265096 \&$ utm medium $=$ social\&utm_source $=$ linkedin $\&$ hss_channel $=$ lcp2670852. Accessed 29 Aug 2021

FIFA (2021) Fifth Report by the FIFA Human Rights Advisory Board. February 2021. https://www.fifa.com/about-fifa/organ isation/committees/news/fifa-human-rights-advisory-boardprovides-closing-report. Accessed 29 Aug 2021

Garciandia R (2020) State responsibility and positive obligations in the European Court of Human Rights: the contribution of the ICJ in advancing towards more judicial integration. Leiden J Int Law 33(1):177-187. https://doi.org/10.1017/S092215651 9000591

Harris DJ et al (2018) Law of the European Convention on human rights, 4th edn. Oxford University Press, Oxford

Hums MA et al (2009) Emerging disability rights in sport: sport as human right for persons with disabilities and the 2006 UN convention on the rights of persons with disabilities. Cambr Law Rev 40(2009):36-48

Human Rights Council (2008) Protect, Respect and Remedy: a Framework for Business and Human Rights: Report of the Special Representative of the Secretary-General on the issue of human rights and transnational corporations and other business enterprises, John Ruggie, A/HRC/8/5, 7 April 2008. https://digitallibrary.un. org/record/625292. Accessed 29 Aug 2021

IOC (2020) Recommendations for an IOC Human Rights Strategy, March 2020. https://stillmed.olympics.com/media/Document\% 20Library/OlympicOrg/News/2020/12/Independent_Expert_ Report_IOC_HumanRights.pdf\#_ga=2.152581049.10786295. 1625481788-1496752458.1625481788. Accessed 29 Aug 2021

Kaufmann-Kohler G, Rigozzi A (2010) Arbitrage international: Droit et pratique à la lumière de la LDIP, $2^{\mathrm{e}}$ édition revue et augmentée. Editions Weblaw 
Katzenstein S (2017) Non-state actors and human rights: legalization and transnational regulation. In: Sandholtz W, Whytock CA (eds) Research handbooks on the politics of international law. Research handbooks in international law series. Edward Elgar Publishing, Cheltenham, pp 336-365. https://doi.org/10.4337/9781783473 984.00021

Lane L (2018) The horizontal effect of international human rights law in practice: a comparative analysis of the general comments and jurisprudence of selected United Nations Human Rights Treaty Monitoring Bodies. Eur J Comp Law Gov 5(1):5-88. https://doi. org/10.1163/22134514-00501001

Lavrysen L (2014) The scope of rights and the scope of obligations: positive obligations. In: Brems E, Gerards J (eds) Shaping rights in the ECHR: the role of the European Court of Human Rights in determining the scope of human rights. Cambridge University Press, Cambridge, pp 162-182. https://doi.org/10.1017/CBO97 81107337923.010

Lavrysen L (2016) Human rights in a positive state: rethinking the relationship between positive and negative obligations under the European Convention on Human Rights. Intersentia, Cambridge

Loven C (2020) "Verticalised" cases before the European Court of Human Rights unravelled: an analysis of their characteristics and the Court's approach to them. Netherlands Q Hum Rights 38(4):246-263. https://doi.org/10.1177/0924051920965753

Mavromati D (2020) Ali Riza et al. v. Turkey - European Court of Human Rights Judgment of 28 January 2020. SportsLegis, published on 31 January 2020. https://www.sportlegis.com/2020/01/ 31/turkish-football/\#easy-footnote-bottom-1-49054. Accessed 29 Aug 2021
Mégret F (2018) Nature of obligations. In: Moeckli D et al (eds) International human rights law, 3rd edn. Oxford University Press, Oxford, pp 86-109

Mowbray AR (2004) The development of positive obligations under the European Convention on Human Rights by the European Court of Human Rights. Hart Publishing, London

Reid K (2015) A practitioner's guide to the European Convention on Human Rights, 5th edn. Sweet \& Maxwell, Mytholmroyd

Schwab B (2019) Protect, respect and remedy: global sport and human rights. Int Sports Law Rev (3):57-70. https://www.uniglobalu nion.org/sites/default/files/files/news/protect_respect_and_remedy_full_article.pdf. Accessed 29 Aug 2021

Stoyanova V (2018) Causation between state omission and harm within the framework of positive obligations under the European Convention on Human Rights. Hum Rights Law Rev 18(2):309-346. https://doi.org/10.1093/hrlr/ngy004

Stoyanova V (2020) Fault, knowledge and risk within the framework of positive obligations under the European Convention on Human Rights. Leiden J Int Law 33(3):601-620. https://doi.org/10.1017/ S0922156520000163

Publisher's Note Springer Nature remains neutral with regard to jurisdictional claims in published maps and institutional affiliations. 